\title{
Climate change and cars in the EU: the roles of auto firms, consumers, and policy in responding to global environmental change
}

\author{
Lorraine Whitmarsh \\ School of Psychology, Cardiff University, Tower Building, Park Place, Cardiff CF10 3AT \\ \& Tyndall Centre for Climate Change Research \\ Telephone: +44(0)2920876972 \\ Fax: +44(0)29 20874858 \\ Email: WhitmarshL@Cardiff.ac.uk \\ Jonathan Köhler \\ Fraunhofer Institute for Systems and Innovation Research \\ Fraunhofer ISI \\ Sustainability and Infrastructure Systems \\ Breslauer Strasse 48, 76139 Karlsruhe, Germany \\ Telephone: +49 (0) $7216809-377$ \\ Fax: +49 (0) $7216809-135$ \\ Email: J.Koehler@isi.fraunhofer.de
}

This is a pre-copy-editing, author-produced PDF of an article accepted for publication in Cambridge Journal of Regions, Economy and Society following peer review. The definitive publisher-authenticated version is available online at: http://cjres.oxfordjournals.org/cgi/content/abstract/rsq008 


\begin{abstract}
Car design, ownership and usage are major determinants of the degree of carbon emissions produced from personal transport. We assess factors influencing environmental innovation in the automotive sector, and behavioural changes of transport consumers in response to climate change and related policies. This analysis highlights the vital role of policy drivers in both supply-side innovation and demand-side change, and considers the efficacy of recent EU policy measures. We argue that the limited progress towards low-carbon transport suggests a need for more interdisciplinary analyses of mobility, and greater attention to psychological, cultural and infrastructural factors affecting demand.
\end{abstract}

Key Words: environmental innovation, automotive industry, transport consumers, behaviour, climate change

JEL code: Z (other special topics)

Acknowledgements: We gratefully acknowledge the comments of two anonymous reviewers on an earlier draft of this paper. 


\section{Climate change and cars in the EU: the roles of auto firms, consumers, and policy in responding to global environmental change}

\section{Introduction}

Climate change and diminishing oil reserves are pressing global and national risks, which demand a concerted response from across all sections of society (e.g., IPCC, 2007). In the context of the requisite shift to a secure, low-carbon energy economy, motor vehicles present a major challenge. Road transport is now one of the largest contributors to emissions of greenhouse gases, and transport is the sector with the highest growth rate of emissions (e.g., Köhler, 2006). Many strategies for tackling greenhouse gas emissions from road transport may also help address broader problems of unsustainability associated with the sector, such as air and noise pollution, congestion, accidents, obesity and inaccessibility of amenities and services (e.g., European Commission, 2001; Nykvist \& Whitmarsh, 2008).

Car design, ownership and usage are clearly major determinants of the degree of carbon emissions produced as a result of personal transport. However, both innovation on the supply side, and change on the consumer side, to reduce greenhouse gas emissions associated with transport have been disappointing. Vehicle technologies to enable a major reduction in emissions are already known in principle and are being actively developed. However, the auto industry has not yet changed its business model to switch to low-emissions technologies as the basis of its products. Environmental innovation is still small-scale, relative to conventional 
motor vehicles with Budd-type pressed steel bodies and internal combustion engines with mechanical transmission (Nieuwenhuis \& Wells, 1997).

Similarly, the public is aware of, and expresses concern about, climate change, but are taking few steps to alter their lifestyles or purchase decisions accordingly. While most people express concern about climate change and are worried about traffic fumes and smog, a minority have cut down on car use for short journeys (DEFRA, 2002). Indeed, research consistently shows there is considerable resistance to changing travel behaviour (e.g., Lethbridge, 2001), which poses challenges for introducing transport demand policies.

The first part of this paper will assess the factors that have influenced supply - environmental innovation decisions in the automotive sector. Our focus is on product-related environmental innovation (i.e. vehicle and fuel technologies and mobility service provision). These innovation decisions have been influenced by policy, economic, socio-cultural and management factors. This analysis particularly highlights the vital role of policy drivers in automotive innovation, and considers the efficacy of recent EU policy measures (e.g., Euro emissions standards, manufacturers' agreements). We also consider how current economic conditions and the maturity of the automotive sector are influencing environmental innovation.

In the second part of this paper, we turn to demand - the consumer side of personal transport. Here, we examine the behavioural changes of transport consumers in response to climate change, and consider to what extent they have been autonomous or policy-driven responses. Again, we focus on recent examples of EU and member state transport policies 
which aim to influence vehicle purchase or usage decisions. These include informational approaches (e.g., energy labelling), economic (dis)incentives (e.g., vehicle or fuel duty, congestion charging), and regulation (e.g., reduced speed limits, low-emission zones) as well as the EU-wide manufacturers' agreements.

Bringing these two sides together, we also consider possible future directions for transport policy given the observed development of supply and demand, as well as changes in sociocultural dimensions of travel and consumption, which are needed to more effectively address climate change.

By considering the responses of automotive firms, transport consumers and policy-makers to major global environmental pressures like climate change, we aim to present a much-needed interdisciplinary perspective drawing on economic and management theories of innovation, the socio-technical transitions literature, and social psychological models of behaviour change. We conclude with areas for further research and policy recommendations for the EU to address the role of personal transport in relation to climate change.

\section{Supply-side innovation: greening the automotive industry}

Factors influencing supply-side innovation

Environmental factors traditionally have low salience in firm decision-making; and tend to be responded to only when they correspond with economic opportunities or regulatory pressures 
(Dyerson \& Pilkington, 2000; Gerard \& Lave, 2005; Weber \& Hoogma, 1998). This tendency is apparent in the case of the automotive industry, which is not only facing strong regulatory pressures to respond to environmental threats like climate change, but in its struggle to survive is also exploring new technological and business opportunities. Different firms adopt diverse strategies with respect to different fuel and vehicle technologies (hybrids, electric, biofuels, hydrogen and fuel cells, gasoline efficiency and exhaust emissions, lightweight chassis and components), and so no one firm can be readily categorised as a 'leader' or 'laggard' with respect to environmental innovation (see Köhler, et al., 2008). Furthermore, some firms (e.g., Toyota) are not only developing new competences in vehicle technologies in response to environmental change, but are also changing their business model away from vehicle production and towards provision of services such as vehicle rental, servicing and finance. Importantly, while these changes have implications for greenhouse gas mitigation, they are primarily a response to regulation and to the state of this mature industry, which is characterised by high capital intensity and low returns (Nieuwenhuis \& Wells, 1997).

Government regulation of the automotive industry has grown from concerns over local air quality, to concerns over greenhouse gas emissions, and now encompasses a broader sustainability agenda with attention given to production methods, material use and disposal (Nieuwenhuis, et al., 2004). Often the objectives behind these policy interventions do not relate solely, or even principally, to environmental improvement, but include broader social and (particularly) economic aims. For example, recent policy measures to foster a 'hydrogen economy' were driven by concerns about energy security and economic competitiveness, as 
well as air quality and carbon emissions (Whitmarsh \& Wietschel, 2008). Similarly, policies to support biofuel technology development are in part responding to the economic needs of industry, including agriculture (Bomb, et al., 2007); while the new 'scrappage' subsidies introduced in Germany and the UK are primarily intended to stimulate demand. The car industry is not passive in this policy development process; rather, the final regulation is usually a compromise position, based on industry-government negotiation (e.g., Hekkert \& van den Hoed, 2006). Nevertheless, the intervention of regulation has significantly improved the environmental performance of vehicles, so that emissions from cars and trucks are many times lower than they were in the 1970s (Nieuwenhuis, et al., 2004). Important in this process is regulator credibility, without which environmental legislation is unlikely to be effective (Gerard \& Lave, 2005). Examples of environmental regulation which have prompted major public and private investment in low-carbon vehicle technologies include the California Air Resources Board's (CARB) Zero Emission Vehicle (ZEV) programme announced in 1990 (Dyerson \& Pilkington, 2000), the 1992 Energy Policy Act and the current Bioenergy Program, prompting investment in flexible-fuel vehicles, and Japanese emissions standards imposed following the US Clean Air Act by the Japanese Ministry of International Trade and Industry (MITI, now METI - Ministry of Economy, Trade and Industry). This latter programme, along with the CARB ZEV mandate, has been a key determinant of Toyota's investment in, and ultimate commercial success with, hybrid electric-ICE vehicles (Ahman, 2006). As we discuss below, the voluntary agreements by European, Japanese and Korean automotive manufacturers have also led to incremental innovation for low-emission vehicles. 
Importantly, though, policy intervention does not necessarily lead to either invention or adoption of more environmentally-benign technologies. This is because there is no guarantee that R\&D will lead to technological breakthrough (Gerard \& Lave, 2005) and there is also a risk that technology-forcing can limit the scope of research and target the wrong technology, effectively locking in an inferior technology. Such considerations undermine the credibility of simple linear models of government policy for innovation, and highlight the importance of preserving technical diversity and allowing for knowledge spillovers (see Ahman, 2006; Service, 2004).

Economic factors - supply and demand - remain critical for R\&D decisions (Cowan \& Hulten, 1996). However, at least until very recently, mainstream automotive markets have continued to demand more energy-intensive products (e.g., SUVs), with increased functionality, comfort and safety as primary concerns above environmental performance (Adamson, 2003). Currently, by contrast, low- and zero-emission vehicles represent only niche markets, such as public procurement, fleet vehicles, and a small proportion of the public willing to pay a premium for improved environmental performance and fuel economy (Lave \& MacLean, 2002). Along with the emergence of automotive markets within developing countries, these trends have serious negative implications for greenhouse gas mitigation. Independent of regulatory requirements, however, there is now a recognition within the auto industry that fossil fuel reserves are depleting, so automotive firms will need to innovate to survive. Furthermore, as a mature industry, there are few technological opportunities for ICE development so radical innovation is needed. In this sense, environmental innovation 
represents one component of a long-term business strategy, for economic sustainability (e.g., Den Hond, 1998; Hoffman, 2001; Vasilash, 2006). Indeed, Daimler-Benz is a 'remarkable case' in that it was not hindered by any Zero Emissions obligations, but still took the lead in fuel cell development because it saw economic opportunities here (van den Hoed, 2004). Even in the short term, however, there is a business case for developing and marketing low- and zeroemission vehicles as a means of conferring a competitive advantage. With car firms increasingly having to compete through non-price methods, some are using 'eco-branding' (see Orsato, 2006) to differentiate themselves from competitors. In particular, Toyota has identified itself as the leader in both environmental and safety features, with its investment in hybrid and accident prevention technologies. Its commitment to hybrid vehicles is indicated in their commercial launch of the technology, several years before it was able to make any profit on it (Hekkert \& van den Hoed, 2006; Lave \& MacLean, 2002). The fear of falling behind can by itself be enough to justify public and private investment in novel automotive technologies, such as proton exchange membrane (PEM) fuel cells, even without evidence of their technical superiority (Maack \& Skulason, 2006; van den Hoed, 2004).

The innovation literature also highlights salient influences at national, global and sector levels on firm innovation strategies or 'styles'. For example, at the national level, government support (including research funding and vehicle purchase subsidies), transport-energy industry collaborations and public acceptance of the energy supply technologies provided a supportive environment for the successful development of electric vehicles in France during the 1990s, which was not evident in other countries (Weber \& Hoogma, 1998). At the sector level within 
the automotive industry there have been several paradigm shifts which have changed firms' production methods, for example the Fordist shift to mass production and the more recent change to 'lean production' (Whipp \& Clark, 1986; Woywode, 2002). In respect of environmental innovation, the automotive culture has traditionally had a constraining influence (see Hoffman, 2001). However, in response to political and economic pressures, auto firms now recognise the need to invest in emissions reduction and other environmental technologies. While lack of take-up by other auto firms may well have influenced firms' decisions to invest in novel environmental technologies, recent studies indicate sector-wide norms exist in respect of preferred technologies for emission reduction. Patent analysis indicates relative homogeneity within the automotive industry in its focus of R\&D: during the 1990s this was primarily in favour of the battery-electric vehicle (BEV); in the early 2000s, there was a shift towards fuel cell and hybrid vehicles (Hekkert \& van den Hoed, 2006); but more recently, there has been a reversal of this trend in favour of BEVs again.

However, it is not only the behaviour of other actors which constrains and influences the decisions of firms in respect of environmental innovations. Skills, equipment and routines restrict the nature of innovation. Core competences of auto firms reside in internal combustion engine and steel chassis development and production (Nieuwenhuis \& Wells, 1997). The industry has been 'locked-in' to these core technologies and practices by complex supply chain arrangements (Peters \& Coles, 2006), sunk investments in equipment, existing skill-set of the labour force, and an industry-wide technological paradigm or 'regime' which embodies taken-for-granted knowledge and institutions (Geels, 2005). These existing 
competences and beliefs contribute to a tendency for incumbent firms to ignore radical innovation and focus efforts on increasing performance of established technologies (Hekkert \& van den Hoed, 2006) and incremental innovation (Dosi, 1984). Technical trajectories within the automotive sector include development of safety features (e.g., air bags); and improved vehicle quality (e.g., four wheel drive, direct injection) and environmental performance (e.g., exhaust gas purification) (Miyazaki \& Kijima, 2000). More radical vehicle innovations - such as battery-powered vehicles and fuel cells - have been initially developed within universities, by firms in other sectors or by enthusiastic amateurs, entrepreneurs or start-ups. The automotive industry has therefore responded to the need for more radical innovations by entering into partnerships with organisations outside the industry. These strategic alliances enable auto firms to move beyond their core competences in ICEs and steel chassis to respond to external (e.g., policy) pressures by introducing novel expertise from outside the automotive regime. This expertise has included electric power-train technologies, as well as lightweight body and chassis components that support a battery propulsion system.

Although a number of authors have highlighted the importance of organisational learning in predicting firm success within the automotive sector (West, 2000), there has been little attempt to link this to environmental innovation. The automotive industry tends to be dominated by concern for the short-term targets, and a propensity to ignore long-term trends (Seidel, et al., 2005). This is particularly the case in the US, where investment/accounting structures restrict organisational flexibility and incentives to innovate (Nieuwenhuis \& Wells, 1997). These pressures tend to militate against environmental innovation for the long term. 
Impact of current economic conditions and maturity of the automobile sector

At the time of writing (mid 2009), the world, including the automotive industry, is experiencing a deep recession. This has emphasised the problems faced by the 'traditional' automobile industry, the most notable event being GM filing for section 12 protection in the US. This means that GM, traditionally the largest auto firm in the world, is effectively bankrupt. In one sense, this means that the auto majors will continue to pursue a conservative technology policy, with only small efforts to develop new low-carbon technologies such as electric vehicles, while their business strategy will be to amalgamate and consolidate. This trend is epitomised by recent strategic alliances, such as the establishment of a cross-shareholding between Suzuki and Volkswagen (Wilkins, 2009). However, these events also indicate that the present structure of the industry is unstable, and that as the current manufacturers struggle to survive, there may be room for new entrants to bring new technological expertise in low carbon technologies into the auto industry.

The maturity of the auto industry and the instability of the transport 'regime' offer opportunities for more radical forms of innovation, including low-carbon innovation. Drawing on the Kondratiev wave and socio-technical transitions literatures, we can identify the motor car as central to the current transport 'regime', which is dominated by personal, automotive travel and ICE technologies (Nykvist \& Whitmarsh, 2008). While there are alternatives, the affordability, dense road network and social groups dispersed across cities and the country make personal mechanised transport by far the most convenient mode for many trips. This is 
combined with a regime which continues to promote a culture supporting positive images of the motor car (Wollen \& Kerr, 2002). However, the motor car culture is beginning to lose its place as the defining cultural icon of modern society. The argument from the Kondratiev wave literature is that the motor car wave has been overtaken by the next wave of computing and the internet (Perez, 2002). This implies that the current regime is actually unstable and is subject to very strong external pressures. As discussed elsewhere (Nykvist \& Whitmarsh, 2008), these include environmental pressures associated with vehicle emissions, physical constraints on the transport system (e.g., congestion, temperature and weather event impacts associated with climate change), and social and health concerns (e.g., obesity, air quality, equity and inclusion). Hence radical change is a real possibility. This makes it easier to imagine a situation where countries change and restrict the use of motor cars. This is reflected in the observation of Nieuwenhuis and Wells (1997) that the cultural status of motor cars may be reduced to that of white goods.

However, from the perspective of the Kondratiev wave literature, if there is no large-scale policy intervention to further promote low-carbon technologies, the most probable developments in the structure of the industry will be similar to other mature industries. While there would still be large numbers of vehicles required, the influence of the motor car industry would decline. Shipbuilding provides a good example of the structure of a mature industry that has not disappeared. Most producers, except for the case of especially complex products, are located in middle-income countries and Japan. Japan and Korea are the largest industries, with Japanese shipbuilders in particular being dependent on continuing subsidies to survive as 
major employers in regions dominated by these industries. Motor vehicle production might follow a similar path. Some companies would survive in name at least. They would continue to offer branded products, but probably with an international logistics chain, based mainly in countries with the most favourable labour markets and tax/subsidy regimes. Hence there would be a large-scale redistribution of industrial activity and employment.

This industrial restructuring might continue to see automotive components manufacturers and suppliers, as well as firms in other sectors, becoming increasingly important (Seidel, et al., 2005). Radical innovation would be possible through partnerships and coalitions of firms within and outside the automotive industry (Dyerson \& Pilkington, 2000; cf. Hendry, et al., 2006). These include niche industries such as biofuels, which comprise networks of automotive, energy and agricultural organisations, and are rapidly becoming profitable and politically-influential in a number of European countries (Bomb, et al., 2007); this had led to promotion of biofuels in the EU notably via the 2003 Biofuel Directive, despite significant criticism about the sustainability of this technology (Nykvist \& Whitmarsh, 2008). Indeed, the empirical literature highlights the central role played by developments in other sectors in automotive innovation. Most recently, this is evident from the increasing integration of electronic and information technologies with the automotive sector, as consumers demand more functionalities with their new cars (Seidel, et al., 2005). In respect of environmental performance, too, knowledge spillovers from other industries have benefited automotive design. This was evident at the birth of the electric car at the end of the nineteenth century when it benefited from battery technology used in electric streetcars (Cowan \& Hulten, 1996); 
more recently advanced battery technologies have been used in the development of hybrid ICE-electric vehicles (Ahman, 2006).

Another possibility for the auto industry to evolve and survive is for large-scale car makers to change their business model. Seidel et al's (2005) 'brand worlds' scenario envisages a shift to mobility service provision not simply vehicle sales (i.e. products to services), as well as an expansion into other consumer products. This is already an emerging trend within the automotive sector as there are more economic opportunities in retail than manufacturing. This involves risks for the firms: Seidel et al. (2005) argue that 'stretching the brand comes at a cost of a loss of focus and a stretching of resources and management attention' (p.446). They quote the experience of Ford, whose core business deteriorated, partly because of excessive diversification. Another possibility is a move towards scaling production runs down to provide a tailor-made vehicle for each customer (Nieuwenhuis \& Wells, 1997).

EU policies to reduce $\mathrm{CO}_{2}$ emissions from automobiles and their effectiveness

As discussed, policy drivers - as well as economic factors - have been key drivers of environmental innovation in the auto industry in the past. Turning to the present, we see EU and member state efforts to tackle climate change and respond to concerns about energy security, air quality, competitiveness and so on, continuing to play an important role in environmental innovation within transport. The main policies that have been applied in the EU on the automotive supply side are summarised in Table 1. 
The main measure implemented so far for passenger cars is the European Automobile Manufacturers' Association (ACEA) voluntary agreement on increased efficiency of new vehicles (EU-wide), which aims to reduce emissions for new cars sold in the EU to $130 \mathrm{~g}$ $\mathrm{CO}_{2} / \mathrm{km}$ average by 2015 , with an additional $10 \mathrm{~g}$ reduction coming from 'complementary measures' including a greater use of biofuels. These measures are supported by a range of policies differentiated between member states, including standards, Liquefied Natural Gas (LNG) subsidies, as well as cross-sector R\&D networks (e.g., for hydrogen and fuel cells). Although we have separated out policies focussed primarily on the demand-side (see Table 2, and the discussion in the following section) for purposes of linking these with different literatures (on industrial innovation and consumer choice/behaviour, respectively), we note that this division is not absolute. Indeed, certain 'demand-side' policies (e.g., labelling) are intended to (and do) influence manufacturers' investment and marketing decisions, as we now discuss.

TNO (2006) provides a comprehensive review of the evidence of the effectiveness of greenhouse gas (GHG) policies and measures (PAMs) for passenger cars. Zachariadis (2006), EEA (2008) and EFTE (2007) review the trends in fuel consumption and specific $\mathrm{CO}_{2}$ emissions for passenger cars. Note that, for diesel and petrol fuels, $\mathrm{CO}_{2}$ emissions are directly proportional to fuel consumption. To summarise, the ACEA agreement has made no observable difference to the long-run trend in specific $\mathrm{CO}_{2}$ emissions. The ACEA agreement has 
led to a moderate improvement in emissions performance of new vehicles, mostly through a switch from petrol to diesel fuel (Fontaras \& Samaras, 2007). This improvement has been offset by a behavioural trend (at least until recently) to purchase larger cars (Zachariadis, 2006). Biofuels promotion policies have had relatively little effect up to 2008 , because they have only recently (mainly since 2005) been introduced.

However, Köhler (2009) finds that the impact of the ACEA agreement has been considerable of the order of $135 \mathrm{Mt} \mathrm{CO}$ for the EU 27 between 1996 and 2007. Based on calculations with the ASTRA model (Schade, 2004), in the year 2005 alone, the savings were around $18 \mathrm{Mt} \mathrm{CO}_{2}$ for the EU15 and $21 \mathrm{Mt} \mathrm{CO}_{2}$ for the EU27. This does not contradict the TNO (2006) conclusion; it just implies that the historical rate of technical progress has been maintained through the voluntary agreement. Other policies are in general assessed by Köhler (2009) to have had little impact.

Given the relative weakness of supporting policies, the impact of the ACEA agreement can be attributed to the highly competitive nature of the automobile industry. This can be argued to act through an 'awareness effect'. The activity of manufactures meeting with the EU Commissions and going through the negotiations to reach an agreement, will have concentrated the attention of manufacturers on the fuel performance of vehicles. Also, the obvious priority placed on emissions performance by the EU could be assumed to reflect a change in the priorities of society. While this has not been demonstrated to a significant extent in consumer choices of new cars, there may be an anticipated shift in preferences in the 
longer run. Therefore, in such a highly competitive market, manufacturers would make increased efforts to improve fuel consumption to ensure that future sales shares were maintained.

While Directive 1999/94/EC provides the basis for adoption of efficiency labelling of cars, TNO (2006) found no measurable effect of labelling policies in the assessment literature. While it cannot be plausibly argued that fuel efficiency is the main consideration of consumers' new car purchases (as we discuss below), fuel efficiency figures are readily available and can be regarded as a point of competition between auto manufacturers. Therefore, the ACEA agreement is likely to have reinforced this effect. However, the non-binding nature of the agreement is clearly demonstrated, in that the agreed ACEA targets have not been met.

The policies discussed above, even if effectively implemented, will only have a moderate impact on the rate of technological progress with regards to GHG emissions from automobiles. Although there is a now a history of environmental policy, its impact has been limited (e.g., Köhler, 2006). As we now discuss, policy measures directed to transport and vehicle consumer demand have also had limited impact, indicating the need for a more holistic approach to fostering low-carbon mobility.

\section{Demand-side innovation: greening vehicle consumer behaviour}

Factors influencing supply-side innovation 
To understand the reasons underpinning consumers' vehicle purchase decisions and modal choice, and in particular why transport policies have produced different results in different countries, we turn to the empirical literature on consumer attitudes and behaviour. Surveys and focus group research highlight public awareness of the problems associated with road transport. In the UK, for example, a majority of the public express concern about air pollution and congestion levels (Lethbridge, 2001). Internationally, awareness and concern about climate change has, in general, been rising steadily in recent years (e.g., DEFRA, 2007). 'Clean' (low- or zero- emission) transport is a central dimension of sustainable transport, as defined by both non-expert publics and expert stakeholder groups (Whitmarsh, et al., 2009b). The public also appears to acknowledge the link between transport and climate change (DEFRA, 2002; King, et al., 2009) particularly when shown a list of possible causes (e.g., Whitmarsh, et al., 2009a). However, unprompted awareness of the links appears to be lower (Whitmarsh, $2009 \mathrm{~b})$, as is awareness of the relative contribution of different transport modes to causing climate change (DfT, 2009). This literature highlights that abstract awareness of the role of fossil fuels (including transport) in causing climate change does not translate into concrete awareness of the role of personal choices and action, including travel behaviour.

Furthermore, neither public awareness of the impacts of transport on climate change, nor increasing levels of reported concern about climate change, is matched by behavioural response to climate change. In general, the public locates responsibility for fostering both sustainable transport and tackling climate change primarily with governments rather than with society or themselves (Whitmarsh, 2009b; Whitmarsh, et al., 2009b). Although the vast 
majority of the public agree that action should be taken to tackle climate change, in general they are more supportive of new technologies or policies to encourage behaviour change (e.g., improved public transport) than increased taxes or tolls which might restrict individual freedom (Poortinga, et al., 2006). When asked about personal lifestyle changes to reduce their environmental impact, most people state they are recycling and conserving energy use in the home (e.g., turning off lights), but a minority say they have changed their travel behaviour (e.g., DEFRA, 2002; Whitmarsh, 2009a). For example, around one-third of the public say they 'always' walk, cycle or take public transport for journeys of under 3 miles; and less than one in ten 'always' car share or use alternatives to travel (e.g., shopping online) (Whitmarsh, et al., 2009a). Furthermore, in both Europe and the US, willingness to change travel behaviour in response to climate change is low (e.g., O'Connor, et al., 2002). Although there is more awareness of the role of transport than of domestic energy use in contributing to climate change, when presented with a list of energy-reduction actions the public is more willing to reduce domestic consumption than to drive or fly less. Indeed, one study (Bibbings, 2004) even found motorists were more aware than non-motorists of the role of driving in contributing to climate change; and another (Barr et al., 2008) found that those aware of the environmental impacts of flying are no less reluctant to reduce the amount they fly. Clearly, this demonstrates that there is a gap between awareness and concern on the one hand, and behaviour on the other (often known as the 'value-action gap'; e.g., Blake, 1999).

From the point of view of transport economics, this disparity may be understood as the product of multiple market failures, arising from externalities in transport (e.g., Rothengatter, 
2001). Two main types of externality are: emissions (greenhouse gases, particulates, and also noise) and congestion, where an individual's decision to use public infrastructure contributes to congestion for all users. However, travel decisions in transport are much more complicated than the conventional rational economic choice model of behaviour would suggest (Köhler, 2006; Small, 2001). Urban form that has developed around roads and cars has created a strong lock-in to automobiles as the primary form of personal transport in wealthy societies. Hiscock et al. (2002) discuss the psychological benefits from car use. This literature demonstrates that, at best, decision-making in transport can be viewed as 'bounded rationality' (Simon, 1956); however, as we now discuss transport behaviour may be a product of multiple motivations or of unconscious habit.

The reasons for the disparity between awareness of transport problems and adoption of sustainable travel behaviours are in part to do with the multiple determinants of travel behaviour, and in part to do with the barriers to low-carbon lifestyle change. First, travel behaviour is not simply (indeed, not often) determined by environmental considerations. Rather, it is an outcome of a complex set of psychological, social, economic, and infrastructural factors. Personal preferences for comfort, convenience, autonomy and so on, clearly play a role in transport choices (e.g., Whitmarsh, et al., 2009b), as do less conscious determinants, such as social identity, symbolism and status associated with vehicle choice and use (e.g., Steg, et al., 2001). Income and pricing of transport options are also important (e.g., Goodwin, et al., 2004), as are infrastructure and availability of alternatives (Köhler, 2006); those living in rural areas are most likely to drive because there are few alternatives available (DEFRA, 2002). 
Where individuals choose to switch to low-carbon alternatives to driving, this is more often out of a desire to save money or for reasons of convenience or health benefits than out of environmental concern (though this may be a secondary reason; Whitmarsh, 2009a).

Second, there are various barriers to changing lifestyles which prevent awareness of transport problems manifesting in behaviour change. While precise knowledge of the relative impacts of different transport modes may by one factor, knowledge deficit is by no means the most important. Institutions and infrastructures serve to lock in carbon-intensive lifestyles, including car dependency. On the social and cultural side, norms and conventions serve to reinforce the assumption that car ownership is a precondition of quality of life and the value of automobility (e.g., Urry, 1999). At the same time, the built environment has developed around - and perpetuated - car dependence, contributing to widespread perceptions of limited (or unattractive) alternatives to driving (Lorenzoni, et al., 2007; Lyons, et al., 2008). The term 'behavioural lock-in' has also been coined (Jackson, 2005) to describe the role of habits in restricting lifestyle change. Travel behaviour is often habitual, and as such difficult to change: individuals with strong car use habits do not consciously deliberate over travel choices or pay attention to information about alternative modes (Verplanken, et al., 1997). This works against the effectiveness of information campaigns. Furthermore, where car use becomes a strong habit, individuals tend to exaggerate the poor quality of alternatives (Fujii, et al., 2001).

Given this background, it is unsurprising therefore that past informational and economic approaches to encouraging transport behaviour change have met with limited success. 
Information will be ignored in the presence of strong habits; and economic motivations are only one amongst many reasons for people's transport choices. Indeed, where economic measures are inappropriately applied, they can lead to public protests, as in the case of the fuel duty protests in the UK in 2001, where hauliers blockaded oil refineries leading to major disruption.

Greater success has been seen for transport demand management policies which are at once equitably enforced and provide viable alternatives to car use. The UK hauliers' protest was in large part due to their perception that the increased duty was unfair to businesses who relied on road transport, a perception that was widely shared by the public who perceived alternative modes to be unfeasible or unattractive and did not in any case accept the rationale for a rise in duty. Revenues from the London Congestion Charge have been used to enhance public transport within the city, thus providing attractive alternatives to car use. The scheme has largely been seen as a success, having reduced congestion without negatively affecting business, and (since its introduction) receiving support from much of the public (Richards, 2006). It is clear that fairness is a key characteristic of acceptable transport policies (King, et al., 2009).

There also needs to be some motivation for changing behaviour. This may be intrinsic or extrinsic. Environmental concern may be enough to encourage some individuals to change, although often this will not occur until they are reconsidering travel options for some other reason (e.g., due to moving house, or changing job). Verplanken et al (2008) for example found 
that environmentally conscious people are more likely to travel to work using slow or public modes if they have recently relocated, compared to environmentally conscious people who have not moved (and therefore may have strong driving habits). Often, the encouragement to change behaviour comes from external incentives, penalties or restrictions - for example, a free one-month bus pass, parking restrictions, or closure of a highway (Bamberg, 2006; Fujii, et al., 2001). In general, such interventions to encourage behaviour change tend to work best when targeted to moments in time when individuals are reconsidering their transport choices, and therefore 'unfreezing' their habits ('habit discontinuity'), such as when relocating or changing job (Verplanken \& Wood, 2006).

\section{Impact of current economic conditions on consumer choices}

Broader economic conditions appear to be having some influence on travel behaviour, although this may be as much to do with reduced numbers of people commuting (due to job cuts) as to modal shift to lower-cost options: in the UK, for example, provisional statistics for 2008 indicate all modes of transport suffered a slight $(<1 \%)$ decrease in demand road traffic. Prior to this, there had been a modest increase in use of public transport in recent years, mostly accounted for by dramatic modal shift in London (DfT, 2008a). Although vehicle purchases in the UK have dropped in recent years (DfT, 2008b), the scrappage scheme has led to an upturn in the market particularly in low-emission vehicles (Lane, 2009).

Summarising this literature, we can say that the public is aware of problems with road transport, including the links with climate change, but that for various cultural, psychological 
and infrastructural reasons, this awareness is not manifested in low-carbon travel behaviour. Where behaviour change has occurred, this is due to the availability of attractive, low-carbon alternatives, and some impetus to try (and sustain use of) these alternatives. This impetus tends to come from extrinsic incentives or restrictions, such as free bus tickets or parking restrictions, which are effectively targeted to both individuals' values and moments of habit discontinuity. As such, we conclude that supply-side environmental innovation, like demandside innovation, has been primarily driven by policy rather than autonomous responses to climate change or pollution (although there may be some influence from current economic conditions).

EU policies aimed at influencing consumer behaviour to reduce $\mathrm{CO}_{2}$ emissions from transport

Table 2 summarises the main policy measures aimed (at least in part) at reducing greenhouse gas emissions through consumer behaviour. These include measures targeted at car purchase and use - such as labelling, differentiated vehicle and fuel taxation, early retirement ('scrappage') and other subsidies - and those aimed more broadly at fostering modal shift and managing demand - such as infrastructure investments and road pricing.

- Insert Table 2 about here -

Evidence from assessments of these policies indicates that measures directed at vehicle purchase choices have had limited impact overall. Energy labelling is information targeted at the point of vehicle purchase, which is infrequent and thus not habitual (i.e., information is 
more likely to be given attention and used in decision-making). However, research suggests that while energy labelling on cars may influence choice between models within a particular class, they are unlikely to significantly shift choices towards more efficient classes of vehicle (Noblet, et al., 2006). This is because energy consumption is only one factor influencing vehicle purchase decisions. Nevertheless, initial outlay is a strong influence on vehicle purchase decisions for many consumers; this explains the success of the scrappage policy in the UK and Germany (Lane, 2009). As noted above, member state economic measures to influence transport behaviour have met with some success, particularly where a package of measures is implemented which improves the attractiveness of public transport relative to car use and is perceived to be equitably enforced.

While these policies have had a modest overall impact within Europe, there are important national differences in their effectiveness. For example, TNO (2006) conclude from their survey that the $\mathrm{CO}_{2}$ taxation introduced by Denmark has had a significant effect on vehicle emissions. The $\mathrm{CO}_{2}$ differentiated tax system introduced in the UK has, in contrast, had no measurable impact on consumers' purchase decisions, although fleet buyers have responded to the fiscal incentives by switching to smaller cars and by not providing company cars (UKERC, 2009). Similarly, national differences in transport and energy policies have contributed to different patterns of consumer vehicle choices: in Sweden, sales of biofuel and flexible-fuel cars have grown rapidly in recent years, while in the UK (where annual mileage is lower and biofuel policies have not been as strong) sales of small cars have grown much more rapidly than alternative fuel vehicles (Nykvist \& Whitmarsh, 2008). Different patterns of 
environmentally-significant behaviour between countries (such as the UK and Sweden), may also reflect different cultural and institutional factors, such as trust in government or environmental beliefs (e.g., Eurobarometer, 2009). These findings point to the importance of physical and cultural factors (such as population density, design of the built environment, environmental values and social norms), as well as national policy priorities, in determining patterns of transport use.

\section{Conclusions and policy implications}

This interdisciplinary review highlights the crucial role of policy in influencing both supply-side and demand-side environmental innovation in transport. We do not advocate a simple linear model of innovation, since environmental policy is no guarantee that R\&D investment will result in technological breakthrough, nor that consumers will accept proposed policies if they perceive them to be inequitable or that low-carbon alternatives are unviable or unacceptable. Sophisticated policy mixes are required which address the range of barriers to behaviour change experienced by transport users, and which also give consideration to pressures and constraints within transport industries in relation to environmental innovation. We have emphasised the psychological, cultural and infrastructural dimensions of consumer demand, which can limit the effectiveness of low-carbon transport measures targeted to consumer choices; and we have highlighted the impact of current global and sector-specific economic conditions as critical drivers of change within the automotive sector. 
In general, innovation on the supply side and change on the consumer side to reduce GHG emissions associated with transport have been disappointing. Voluntary measures inevitably meet with very limited success because of prevailing psychological, economic, social and cultural pressures not to change. On the other hand, the most effective policies for reducing GHG emissions associated with transport have been those which exploit and encourage competitiveness within the auto industry, provide attractive alternatives to high-emission vehicles (or car use in general) and are perceived to be fair. Interestingly, labelling of new cars appears to have had more effect on environmental innovation on the supply side than (so far) on the consumer side because it has stimulated competition amongst firms but provides only one informational input to complex consumer decision-making processes about vehicle choice.

While we have only briefly considered mobility from the point of view of alternatives to car use in this paper, we have highlighted the complex factors involved in individual choices about mobility and the need for policy mixes which give attention to cultural and infrastructural factors as well as to individual knowledge and motivations. Retaining the benefits of modern transportation, while achieving clean transport, requires large-scale changes. Directed processes of change - transitions - to new forms of transport are required, in terms of technology, the structure of the built environment, and lifestyles and culture. This change should be sensitive to particular regional and local contextual factors - such as behavioural norms, socio-demographics and population density, planning and land use policies, and available infrastructure and transport services - which, as we have discussed, can vary substantially between and within countries (e.g., urban, suburban, rural). 
An analysis in terms of transitions takes us into non-linear dynamic processes. It is not just a matter of developing a policy and then extrapolating the effects forward through time; it requires the consideration of how to initiate social and economic processes that will transform transportation. The socio-technical transitions literature is helpful here (e.g., Geels, 2005; Nykvist \& Whitmarsh, 2008), and recent analysis in this field suggests there is promise in 'strategic niche management' which stimulates and protects diverse forms of radical innovation (Kemp, et al., 1998). The lessons from past transitions include the importance of both external and internal pressures on industries and the sector at large in creating the conditions whereby radical innovations can be upscaled and replace the current regime. The maturity of the car industry and broader instability of the transport regime indicate that radical transformation through auto firms partnering with other (e.g., IT) industries and changing their business model will increasingly occur and could contribute to a lower-carbon transport future. On the consumer side, current economic conditions are also influencing behaviour to some extent, and it is interesting to consider whether habits formed now will be retained when economic conditions improve. This is just one area in which future research could be focussed. More generally, there is a need to provide further interdisciplinary and holistic analyses of potential low-carbon transitions within mobility that considers the interplay of structural, organisational, individual and policy factors.

\section{References}


Adamson, K.-A. 2003. An examination of consumer demand in the secondary niche market for fuel cell vehicles in Europe. International Journal of Hydrogen Energy, vol. 28, 771-780.

Ahman, M. 2006. Government policy and the development of electric vehicles in Japan. Energy Policy, vol. 34, 433-443.

Bamberg, S. 2006. Is a residential relocation a good opportunity to change people's travel behavior? Results from a theory-driven intervention study. Environment and Behavior, vol. $38,820-840$.

Barr, S., T. Coles, \& G. Shaw. 2008. Changing behaviours for a changing climate: a lifestyles approach. Paper presented at International Conference on Climate change impacts and adaptation: Dangerous rates of change. Sept 22nd-24th. Exeter, UK.

Bibbings, J. 2004. Climate concern: Attitudes to climate change and windfarms in Wales, Cardiff, Welsh Consumer Council and Friends of the Earth Cymru.

Blake, J. 1999. Overcoming the 'Value-Action Gap' in Environmental Policy: tensions between national policy and local experience. Local Environment, vol. 4, 257-278.

Bomb, C., McCormick, K., Deurwaarder, E., \& Kaberger, T. 2007. Biofuels for transport in Europe: lessons from Germany and the UK. Energy Policy, vol. 35, 2256-2267.

Cowan, R., \& Hulten, S. 1996. Escaping lock-in: the case of the electric vehicle. Technological Forecasting \& Social Change, vol. 53, 61-79.

DEFRA 2002. Survey of public attitudes to quality of life and to the environment: 2001, London, Department for Environment, Food and Rural Affairs. 
DEFRA 2007. Survey of Public Attitudes and Behaviours toward the Environment: 2007, London, Department for Environment, Food and Rural Affairs.

Den Hond, F. 1998. The 'Similarity' and 'Heterogeneity' Theses in Studying Innovation: Evidence from the End-of-Life Vehicle Case. Technology Analysis and Strategic Management, vol. 10, 529-543.

DfT 2008a. Transport Statistics Great Britain: 2008 edition, www.dft.gov.uk/pgr/statistics/datatablespublications/tsgb/2008edition/.

DfT 2008b. Vehicle licensing 2008, <http://www.dft.gov.uk/pgr/statistics/datatablespublications/vehicles/licensing/vehiclel icensingstatistics2008>.

DfT 2009. Public attitudes towards climate change and the impact of transport: 2006, 2007 and 2008, http://www.dft.gov.uk/adobepdf/162469/221412/221513/4387741/climatechngandtra nsport.pdf.

Dosi, G. 1984. Technical Change and Industrial Transformation, London, Macmillan.

Dyerson, R., \& Pilkington, A. 2000. Innovation in complex systems: regulation and technology towards the electric vehicle. International Journal of Innovation Management, vol. 4, 3349.

ECMT 2007. Cutting Transport CO2 Emissions: What Progress? , Paris, OECD.

EEA 2008. Climate for a transport change TERM 2007: indicators tracking transport and environment in the European Union, EEA Report No 1/2008, EEA. 
EFTE 2007. Reducing CO2 Emissions from New Cars: A Study of Major Car Manufacturers' Progress in 2006, Brussels, European Federation for Transport and Environment.

Eurobarometer 2009. Special Eurobarometer 300. Europeans' attitudes towards climate change,

Brussels, European Commission.

http://ec.europa.eu/public_opinion/archives/ebs/ebs_300_full_en.pdf. Accessed $20 / 01 / 2010$

European Commission 2001. European transport policy for 2010: time to decide. White Paper. Brussels: European Commission.

Fontaras, G., \& Samaras, Z. 2007. A quantitative analysis of the European Automakers' voluntary commitment to reduce $\mathrm{CO} 2$ emissions from new passenger cars based on independent experimental data. Energy Policy, vol. 35, 2239-2248.

Fujii, S., Garling, T., \& Kitamura, R. 2001. Changes in drivers' perceptions and use of public transport during a freeway closure: Effects of temporary structural change on cooperation in a real-life social dilemma. Environment and Behavior, vol. 33, 796-808.

Geels, F. W. 2005. Technological Transitions and System Innovations: A Co-evolutionary and Socio-Technical Analysis, Cheltenham, Edward Elgar.

Gerard, D., \& Lave, L. B. 2005. Implementing technology-forcing policies: The 1970 Clean Air Act Amendments and the introduction of advanced automotive emissions controls in the United States. Technological Forecasting \& Social Change, vol. 72, 761-778.

Goodwin, P., Cairns, S., Dargay, J., Hanly, M., Parkhurst, G., Stokes, G., et al. 2004. Changing travel behaviour. Paper presented at the Presentation given at the Bloomsbury Theatre, London. 
Hekkert, M., \& van den Hoed, R. 2006. Competing technologies and the struggle towards a new dominant design: the emergence of the hybrid vehicle at the expense of the fuel cell vehicle? In P. Nieuwenhuis, P. Vergragt \& P. Wells (Eds.), The Business of Sustainable Mobility: From vision to reality. Sheffield: Greenleaf Publishing.

Hendry, C., Harbourne, P., \& Brown, J. 2006. Fuel cell strategies for regime change in stationary power. Paper presented at the SPRU 40th Anniversary Conference - The Future of Science, Technology and Innovation Policy.

Hiscock R., Macintyre S., Keams A. \& Ellaway A. 2002. Means of transport and ontological security: Do cars provide psycho-social benefits to users? Transportation Research Part D, vol. 7, 119-135.

Hoffman, P. 2001. Tomorrow's Energy: Hydrogen, Fuel Cells and the Prospects for a Cleaner Planet, Boston, MIT Press.

IEA 2008. WEO Policy Database <http://www.iea.org/Textbase/pm/?mode=weo>.

IPCC 2007. The Physical Science Basis. Summary for Policymakers. Contribution of Working Group I to the Fourth Assessment Report of the Intergovernmental Panel on Climate Change, Geneva, IPCC.

Jackson, T. 2005. Motivating sustainable consumption: A review of evidence on consumer behaviour and behavioural change, Guildford, Sustainable Development Research Network:

http://www.sdresearch.org.uk/researchreviews/documents/MotivatingSCfinal_000.pdf. 
Kemp, R., Schot, J., \& Hoogma, R. 1998. Regime shifts to sustainability through processes of niche formation: The approach of Strategic Niche Management. Technology Analysis and Strategic Management, vol. 10, 175-195.

King, S., Dyball, M., Webster, T., Sharpe, A., Worley, A., DeWitt, J., et al. 2009. Exploring public attitudes to climate change and travel choices: deliberative research. Final report for Department for Transport, http://www.dft.gov.uk/pgr/scienceresearch/social/climatechange/attitudestoclimatecha nge.pdf, People Science \& Policy Ltd \& ITS, Leeds.

Köhler, J. 2006. Transport and the environment: the need for policy for long term radical change: A literature review for the DTI FORESIGHT project on Intelligent Infrastructure Systems. IEE Proc. Intelligent Transport Systems, vol. 153.

Köhler, J. 2009. Case Study ACEA Agreement, Report for EU GHG-PAM project, Karlsruhe, Fraunhofer ISI.

Köhler, J., Whitmarsh, L., Michie, J., \& Oughton, C. (2008). Can car makers save the planet? In T. Foxon, J. Köhler \& C. Oughton (Eds.), Innovation for a Low Carbon Economy: Economic, Institutional and Management Approaches (pp. 230-272). Cheltenham: Edward Elgar.

Lane, B. 2009. Is the car scrappage scheme helping the environment? , vol., < http://www.guardian.co.uk/environment/ethicallivingblog/2009/aug/2021/carscrappage-carbon-emissions>.

Lave, L. B., \& MacLean, H. L. 2002. An environmental-economic evaluation of hybrid electric vehicles: Toyota's Prius vs. its conventional internal combustion engine Corolla. Transportation Research Part D, vol. 7, 155-162. 
Lethbridge, N. 2001. Transport trends: Understanding attitudes to transport policy, DETR, www.dft.gov.uk/pgr/statistics/datatablespublications/trends/2001articles/article2under $\underline{\text { standingattitud5436 }}$

Lorenzoni, I., Nicholson-Cole, S., \& Whitmarsh, L. 2007. Barriers perceived to engaging with climate change among the UK public and their policy implications. Global Environmental Change, vol. 17, 445-459.

Lyons, G., Goodwin, P., Hanly, M., Dudley, G., Chatterjee, K., Anable, J., et al. 2008. Public attitudes to transport: Knowledge review of existing evidence. Report for Department for Transport.

Maack, M. H., \& Skulason, J. B. 2006. Implementing the hydrogen economy. Journal of Cleaner Production, vol. 14, 52-64.

Miyazaki, K., \& Kijima, K. 2000. Complexity in Technology Management: Theoretical Analysis and Case Study of Automobile Sector in Japan. Technological Forecasting and Social Change, vol. 64, 39-54.

Nieuwenhuis, P., Vergragt, P. J., \& Wells, P. 2004. Technological change and regulation in the car industry. Greener Management International: The Journal of Corporate Environmental Strategy and Practice (GMI), vol. Autumn, 5-11.

Nieuwenhuis, P., \& Wells, P. 1997. The Death of Motoring? Car making and automobility in the 21st century, New York, John Wiley \& Sons.

Noblet, C. L., Teisla, M. F., \& Rubin, J. 2006. Factors affecting consumer assessment of ecolabeled vehicles. Transportation Research Part D: Transport and Environment, vol. 11, $422-431$. 
Nykvist, B., \& Whitmarsh, L. 2008. A multi-level analysis of sustainable mobility transitions: Niche development in the UK and Sweden. Technological Forecasting \& Social Change, vol. $75,1373-1387$.

O'Connor, R. E., Bord, R. J., Yarnal, B., \& Wiefek, N. 2002. Who wants to reduce greenhouse gas emissions? Social Science Quarterly, vol. 83, 1-17.

Orsato, R. 2006. Competitive environmental strategies: When does it pay to be green? California Management Review, vol. 48, 127-143.

Perez, C. 2002. Technological Revolutions and Financial Capital, Cheltenham UK; Northampton MA, USA, Edward Elgar.

Peters, S. R., \& Coles, A.-M. 2006. Strategic innovation in sustainable technology: the case of fuel cells for vehicles. International Journal of Environment and Sustainable Development, vol. 5, 338 - 354.

Poortinga, W., Pidgeon, N., \& Lorenzoni, I. 2006. Public Perceptions of Nuclear Power, Climate Change and Energy Options in Britain: Summary Findings of a Survey Conducted during October and November 2005. Understanding Risk Working Paper 06-02, Norwich, UK, School of Environmental Sciences, University of East Anglia.

Richards, M. G. 2006. Congestion Charging in London. The Policy and the Politics, Palgrave Macmillian.

Rothengatter, W. 2001. External Effects of Transport. In: J.B. Polak \& A. Heertje (eds) Analytical Transport Economics: An international perspective (pp.79-116), Cheltenham UK, Edward Elgar. 
Schade, W. 2004. Strategic Sustainability Analysis:Concept and application for the assessment of European transport policy, Karlsruhe Papers in Economic Policy Research No. 17, University of Karlsruhe, Germany, IWW.

Seidel, M., Loch, C. H., \& Chahil, S. 2005. Quo vadis, automotive industry? A vision of possible industry transformations. European Management Journal, vol. 23, 439-449.

Service, R. F. 2004. The hydrogen backlash. Science, vol. 13 August, 958-961.

Simon, H. 1956, Rational choice and the structure of the environment. Psychological Review, vol. 63, 129-138.

Small, K. A. 2001. Urban Transportation Economics, London, Routledge.

Steg, L., Vlek, C., \& Slotegraaf, G. 2001. Instrumental-reasoned and symbolic-affective motives for using a motor car. Transportation Research Part F: Traffic Psychology and Behaviour, vol. 4, 151-169.

TNO 2006. Review and Analysis of the reduction potential and Costs of Technological and Other Measures to Reduce CO2-emissions from Passenger Cars, Final report, Delft, TNO.

UKERC 2009. What policies are effective at reducing carbon emissions from surface passenger transport?

UKERC, http://www.ukerc.ac.uk/ResearchProgrammes/TechnologyandPolicyAssessment/TPAPro jects.aspx, Accessed 12/09/2009.

Urry, J. 1999. Automobility, Car Culture and Weightless Travel: A discussion paper. Lancaster, UK: Department of Sociology, Lancaster University. 
van den Hoed, R. 2004. Driving Fuel Cell Vehicles: How established industries react to radical technologies, Delft, The Netherlands, Faculty of Industrial Design Engineering, Delft University of Technology.

Vasilash, G. 2006. An inconvenient truth: GM cares about the environment. Automotive Design and Production, vol. August.

Verplanken, B., Aarts, H., \& van Knippenberg, A. 1997. Habit, information acquisition, and the process of making travel mode choices. European Journal of Social Psychology, vol. 27, 539-560.

Verplanken, B., Walker, I., Davis, A., \& Jurasek, M. 2008. Context change and travel mode choice: Combining the habit discontinuity and self-activation hypotheses. Journal of Environmental Psychology, vol. 28, 121-127.

Verplanken, B., \& Wood, W. 2006. Interventions to break and create consumer habits. Journal of Public Policy and Marketing, vol. 25, 90-103.

Weber, M., \& Hoogma, R. 1998. Beyond national and technological styles of innovation diffusion: a dynamic perspective on cases from the energy and transport sectors. Technological Analysis and Strategic Management, vol. 10, 545-566.

West, P. 2000. Organisational Learning in the Automotive Sector, London, Routledge.

Whipp, R., \& Clark, P. 1986. Innovation and the Auto Industry: Product, process and work organization, London, Frances Pinter (Publishers) Limited.

Whitmarsh, L. 2009a. Behavioural responses to climate change: Asymmetry of intentions and impacts. Journal of Environmental Psychology, vol. 29, 13-23. 
Whitmarsh, L. 2009b. What's in a name? Commonalities and differences in public understanding of 'climate change' and 'global warming'. Public Understanding of Science, vol. 18, 401420.

Whitmarsh, L., O’Neill, S., Seyfang, G., \& Lorenzoni, I. 2009a. Carbon Capability: what does it mean, how prevalent is it, and how can we promote it? , Tyndall Working Paper, No.132. www.tyndall.ac.uk.

Whitmarsh, L., Swartling, Å., \& Jäger, J. 2009b. Participation of experts and non-experts in a sustainability assessment of mobility. Environmental Policy \& Governance, vol. 19, 232250.

Whitmarsh, L., \& Wietschel, M. 2008. Sustainable transport visions: What role for hydrogen and fuel cell vehicle technologies? Energy and Environment, vol. 19, 207-226.

Wilkins, D. 2009. Volkswagen and Suzuki link up. Thursday, 10 December. www.independent.co.uk. Accessed 20/01/2010.

Wollen, P., \& Kerr, J. (Eds.). 2002. Autopia: cars and culture. London: Reaktion Books.

Woywode, M. 2002. Global management concepts and local adaptations: Working groups in the French and German car manufacturing industry. Organization Studies, vol. 23, 497-524.

Zachariadis, T. 2006. On the baseline evolution of automobile fuel economy in Europe. Energy Policy, vol. 34, 1773-1785. 
Table 1. Summary of EU emissions reduction policies for automobiles (supply-side)

MEASURE

\section{EU Measures}

- ACEA agreement

- Car labelling (energy efficiency)

Complementary to ECCP1 (European Climate Change Programme I)

- EU Biofuels Directive

- CAP EU subsidy €45/ha for energy crops since 2003 up to $1.5 \mathrm{Mha}$ for whole of EU

- Vehicles in EU Emissions Trading System (ETS)

Technology promotion measures

- R\&D networks (e.g. $\mathrm{H}_{2}$ )

- Subsidies for technology development

- Biofuel production subsidies

- Biofuels quotas and warranty

- Technical standards

- Voluntary agreements

- LNG directive

- LNG policies - as for biofuels

Measures for Vehicle Components - tyres, lubricants, air conditioning systems

- Standards
GOAL FOR TOP-DOWN IMPACT

$140 \mathrm{~g} \mathrm{CO}_{2} / \mathrm{km}$ average for new cars sold in EU in $2008\left(130 \mathrm{~g} \mathrm{CO}_{2} / \mathrm{km}\right.$ by 2015)

Sources: ECMT (2007), WEO Policy Database (IEA, 2008) 
Table 2. Summary of EU emissions reduction policies for automobiles (demand-side)

MEASURE

GOAL FOR TOP-DOWN

IMPACT

\section{EU Measures}

- Car labelling (energy efficiency)

Complementary to ECCP1

- Fuel taxes

- Annual Vehicle registration taxes differentiated by GHG implications

- Car purchase tax (VAT)

Technology promotion measures

- Tax reductions on biofuels and LNG

(reduction in overall greenhouse gas emissions from automobiles)

- Consumer/retailers' information campaign

Measures for Vehicle Components - tyres, lubricants, air conditioning systems

- Labelling

- Subsidies

\section{Consumer measures}

- Subsidies for early retirement ('scrappage')

Infrastructure measures

- Road pricing

- Subsidies for new control, monitoring technologies

- Public expenditure on infrastructure for GHG-PAMs

Sources: ECMT (2007), WEO Policy Database (IEA, 2008) 